石油技術協会誌 第 79 巻 第 5 号 （平成 26 年 9 月） $292 \sim 295$ 頁 Journal of the Japanese Association for Petroleum Technology Vol. 79, No. 5 (Sept., 2014) pp. 292 295

\begin{tabular}{l}
\hline 講 演 \\
Lecture \\
\hline
\end{tabular}

セッション 2 : ケーシング・セメンチング作業の分析から得た教訓 ${ }^{*}$

福 嶋 直 哉**

(Received August 22, 2014 ; accepted October 10, 2014)

\title{
Lessons learned from analysis of casing and cementing operations
}

Naoya Fukushima

\begin{abstract}
It was concluded that hydrocarbon flow occurred through the $7^{\prime \prime} \times 9-7 / 8^{\prime \prime}$ production casing from the shoe track. A combination of casing design (long-strings or liner), cementing program, temporary abandonment plan, failure of function of float collar, contamination / channeling of cement were possible causes of hydrocarbon flow. A mitigation plan to prevent blowout is proposed and discussed in this paper.
\end{abstract}

Keywords : Macondo, casing design, cementing design, float collar, temporally abandonment, annular pressure build up

\section{1.はじめに}

メキシコ湾原油流出事故に至る経緯のうち, シンポジウ ムのセッション 2 では事故後の米国政府の調査により事故 の原因と推定されたフローパスの 3 つのシナリオについて 説明し, 海洋におけるインターベンション作業で判明した 事実からケーシング内からのフローパスが事故の原因と結 論付けられた理由について述べる。次にこの結論に至つた ケーシングおよびセメンチングデザインの問題点を抽出 し，考えられる対策を提案するとともに，仮廃坑計画に対 する考え方についても言及する。

\section{2. フローパス}

\section{1 フローパスの推定 -3 つのシナリオ}

フローパスのシナリオとして以下の 3 つのシナリオが推 定された。

シナリオ 1 : アニュラスのセメントが効いておらず, ア ニュラスよりフローした。

シナリオ $2 ：$ アニラスのセメントが効いておらず，さら にケーシングが破損し，アニュラスおよび管 内からフローした。

シナリオ 3 ： シュートラックの破損により管内からフロー した。

\footnotetext{
平成 26 年 6 月 4 日, 平成 26 年度石油技術協会春季講演会作井部門 シンポジウム「メキシコ湾原油流出事故の総括」で講演 This paper was presented at the 2014 JAPT Drilling Symposium entitled "Lessons Learned from the blowout in Gulf of Mexico" held in Niigata, Japan, June 4, 2014.

***出光オイルアンドガス開発(株) Idemitsu Oil \& Gas Co., Ltd.
}

\section{2 インターベンション作業で判明した事実}

ROV による観察およびインプレッションツール (Impression Tool) による測定により, シールアッセンブリーがウェ ルヘッドの定位置にセットされていたことが確認でき，さ らにロックダウンスリーブをセットし，5,200 psi の圧力を 保持できたことから, ケーシングハンガーが正規の位置に セットされていることが判明した。回収した BOP の調査 結果によりケーシングハンガーとシールアッセンブリーに は浸食が見られなかったが, ブラインドシアラム内部に浸 食が確認された。

9-7/8" ケーシングのアニュラスに $13.2 \mathrm{ppg}$ の泥水を用い て加圧テストを実施し 4,158 psi を保持した。管内に 14.3 ppg の泥水を満たし, 9,176〜9,186ft 間にパーフォレーショ ンを実施した結果，管内からアニュラスへの U-チューブ フローがなく, またアイソレーションスキャナーツール (Isolation Scanner Tool) による検層の結果, アニュラスに はフリーガスが存在しないことを確認した。

\section{3 フローパスの特定}

アニュラスの加圧テストで圧力を保持したこと，管内か らアニュラスへのU-チューブフローがなかったこと, ア ニュラスにフリーガスが存在しなかったこと, さらにケー シングハンガーとシールアッセンブリーには浸食が認めら れなかったことより, シナリオ 1 および 2 の可能性は否定 された。

ブラインドシアラム内部に確認された浸食は, 高圧力の 流体（ハイドロカーボン）がフローしたことによる浸食と 判断し, ハイドロカーボンはシュートラックの破損により ケーシング管内からフローしたと結論づけられた。 


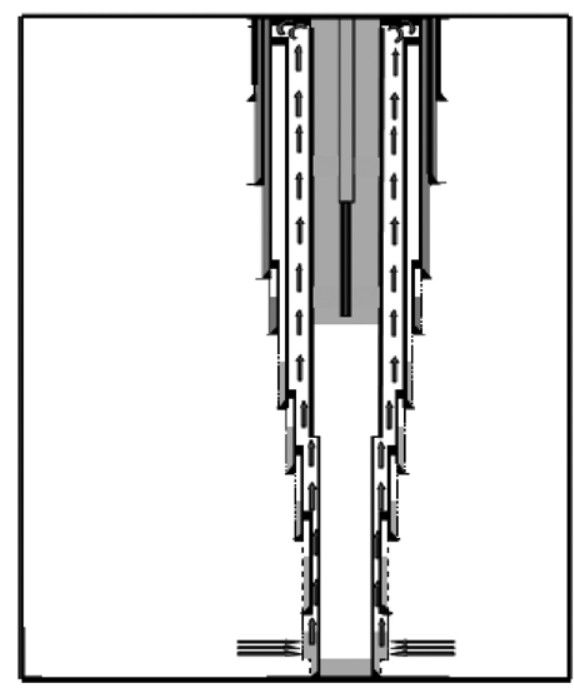

シナリオ 1

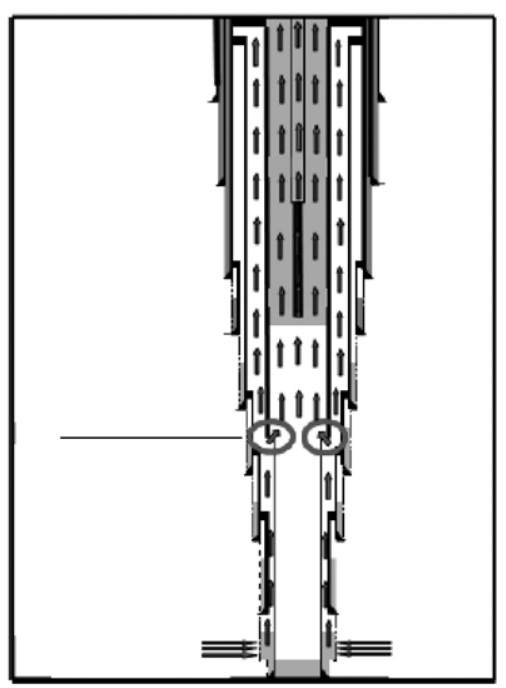

シナリオ 2

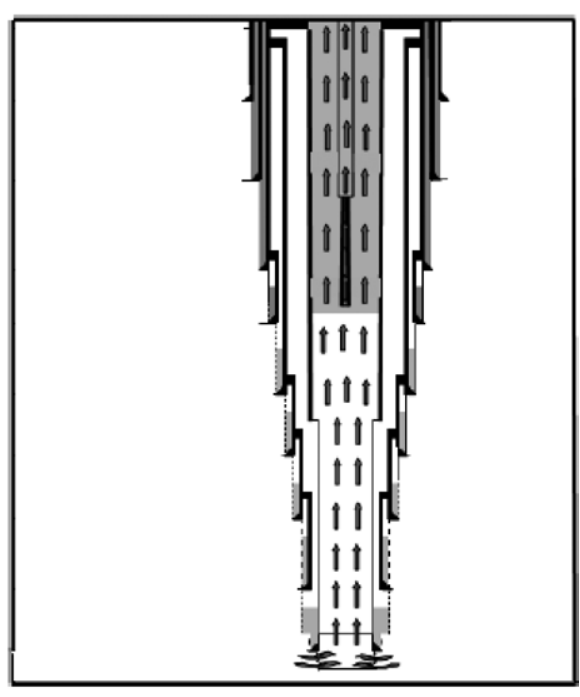

シナリオ 3

図 1 フローパスのシナリオ

\section{4 シュートラック破損の原因}

シュートラックが破損した原因は，ロングストリングを 選定したことおよび不完全なセメントデザインによる泥水 とセメントのコンタミ，セメントと泥水の置換， N2 セx ントの窒素とセメントの分離，オーバーディスプレイスメ ントおよびフロートカラーの破損が挙げられた。

\section{3. ケーシングデザイン}

当初 7" $\times 9-7 / 8^{\prime \prime}$ ケーシングのロングストリングを採用 する計画であった。しかし，セメンチングモデルシミュ レーションの結果，セメンチング中に地層破壊を起こしセ メンチングが失敗する可能性が高く，セメントを貯留層の 上 $500 \mathrm{ft}$ まで上げるという基準を見たなさないことが予想 され，セメンチング失敗による補修セメンチングを実施す

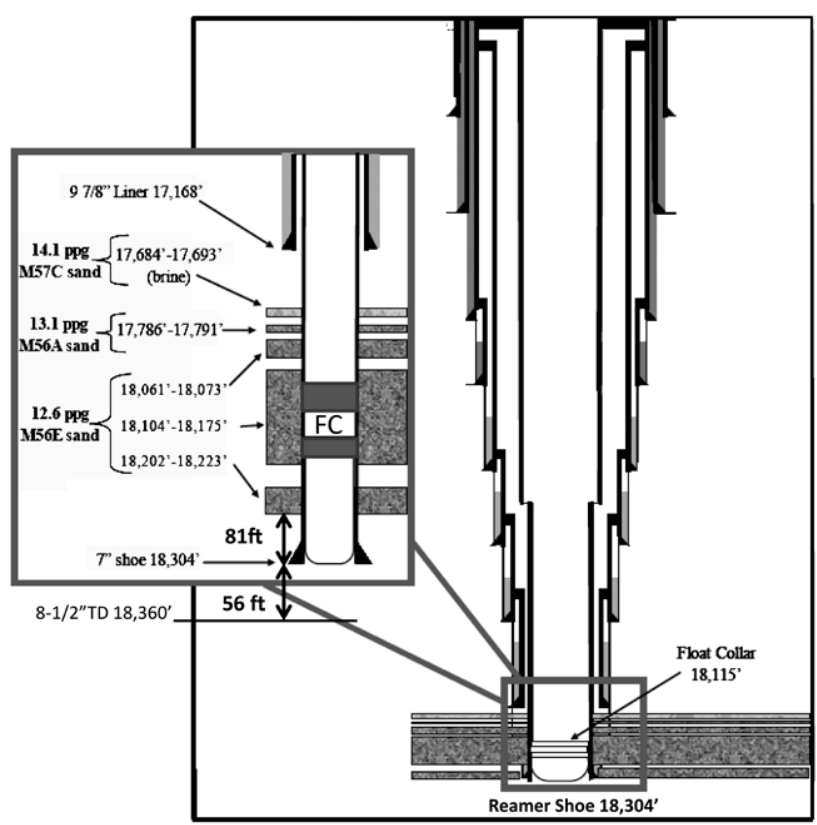

図 2 坑 内 図
る可能性が高いことが示唆された。さらにロングストリン グの場合裸坑部を含めウェルヘッドまでのアニュラスがセ メントで充填されないため, ウェルヘッドシールアッセン ブリーしかバリアがないことから 7"ライナーの採用を推 奨した。

7"ライナーのセメンチングではロングストリングに比 べ等価循環泥水比重が低くセメンチング中に地層破壊を起 こす可能性が低いこと, ライナータイバックによりタイ バックセメンチングとタイバックシールの 2 つのバリアが 得られることからライナーの優位性も認識していた。

しかしながら, その後のセメンチングモデルシミュレー ションでロングストリングの場合でもセメンチング中に地 層破壊を起こす可能性は低く, セメンチングが成功する結 果が出たこと，仕上げ費用がライナーに比べ $700 〜 1,000$ 万ドル安価であることから最終的にロングストリングを選 択した。

ロングストリングおよびライナー以外のオプションとし て，いずれのケーシングもセットせず，裸坑部にセメント プラグをセットして仮廃坑する第 3 のオプションを認識し ていたが，このオプションはあくまで坑内状況が悪い場合 のオプションであること, セメント浚いや電検のやり直し による支出が 1,000 ～1,500 万ドルと多額であることから 採用は見送られた。

\section{4. セメンチング}

\section{1 セメンチングデザイン}

セメントデザインとモデリングは, セメンチング中の 逸泥を軽減することに集中した結果, セメントコラムを 最小限にすることとしたため, セメントスラリー量は 51 bbl と少量にし, 窒素セメントの使用と低ポンプレート（4 BPM）でセメンチングを実施する計画とした。セメント スラリーは, リードスラリー $5.2 \mathrm{bbl}$, 窒素セメントスラリー $38.9 \mathrm{bbl}$, テールスラリー $6.9 \mathrm{bbl}$ で, スペーサーはベース 


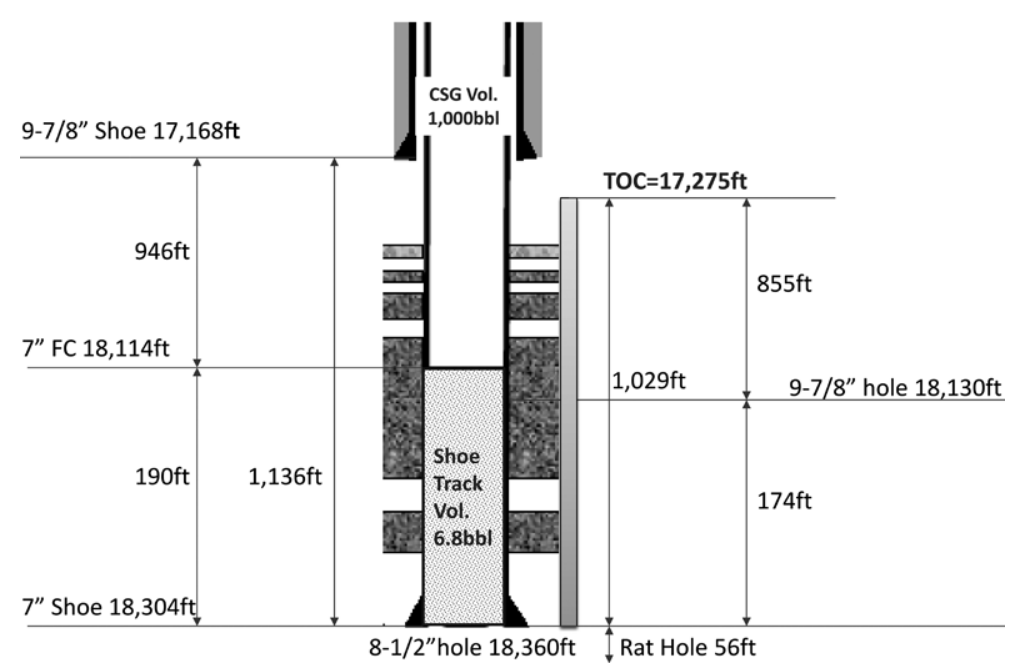

図 3 坑内図一拡大
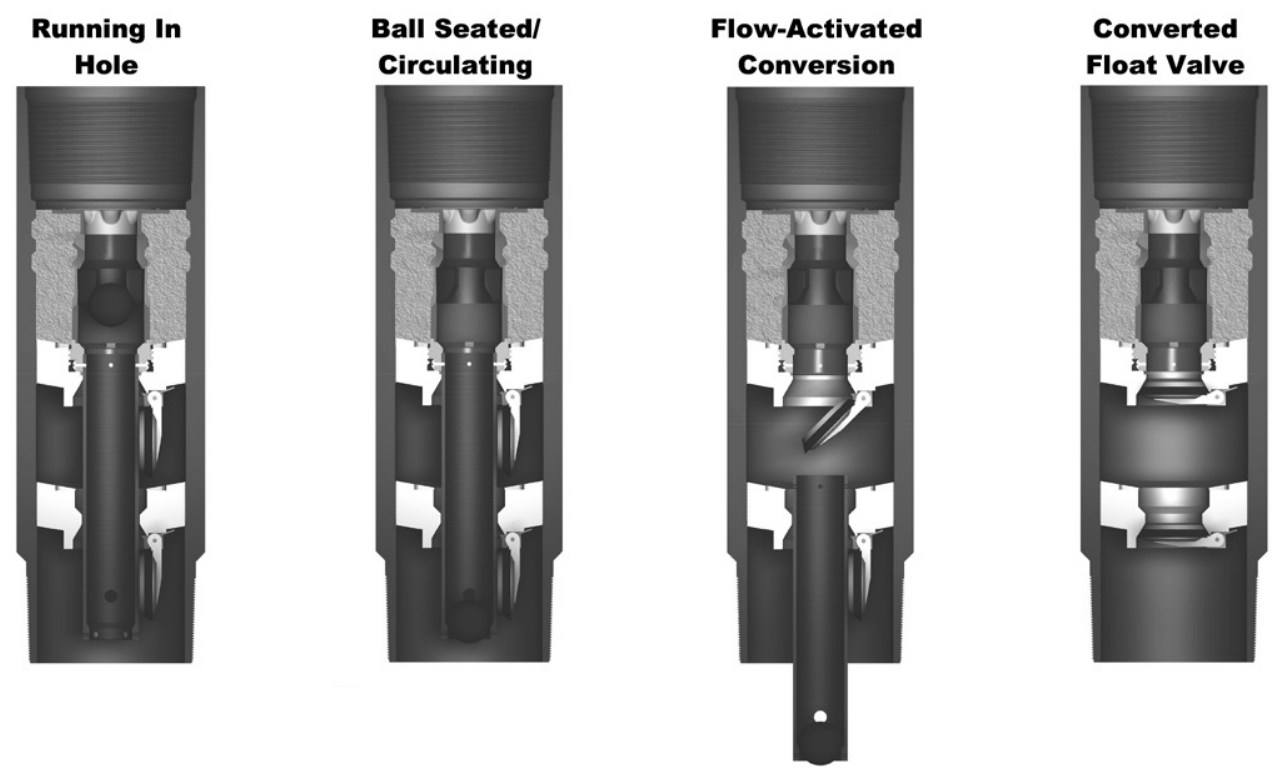

図 4 Auto-Fill Up 機能付, Double Check Valve Weatherford Model 45AP

オイル, 先行水, 後行水が計画された。セメントボンドロ グ測定のための捨て穴を確保するため, フロートカラー上 にはセメントを置かない計画であった。

また，アニュラス圧力上昇を防止するため，9-7/8”ケー シング管内までセメントを上げない計画とした。

セメントの圧縮強度試験は完了しておらず，高いガスフ ローポテンシャルが指摘されていたが，このリスクを適切 に分析，評価していなかった。

\section{2 セメンチング作業}

捨て穴に重泥水をスポットすることなくケーシングを降 下し，またセメンチング前の循環では逸泥を懸念し，ボト ムアップすることなくセメンチング作業を実施した。

フロートカラーをオートフィルアップポジションから循 環ポジションにコンバートするために 9 回の加圧を必要と し, 最終的に $3,142 \mathrm{psi}$ で循環ポジションにコンバートで きた。通常は，コンバートにはポンプレート $5 〜 7$ BPM, 差圧 400 〜 700 psi が必要だが, 4 BPM で循環したため,
十分な差圧が得られず，コンバートが成功しなかったと考 えられる。

また, セメンチング前にボトムワイパープラグを投入し， フロートカラーに到着後ラプチャーディスクを破るために 設計圧力 $900 \sim 1,000$ psi に対し 2,900 psi の加圧が必要で あった。これらの事実は, フロートカラーに何らかの異常 （異物の詰まり，破損など）があることを示唆していた。

セメンチング作業終了後 15〜20 分間フローバック をチェックしたところ, ペンシルストリーム (pencil stream）が見られたもののリグのヒービングの影響と判断 し, フロートカラーのバックバルブは効いていると判断 した。

\section{5. 問 題 点}

5.1 ケーシングデザイン

ロングストリングの管内容量約 $1,000 \mathrm{bbl}$ に比べ，セメ ントスラリー容量が $51 \mathrm{bbl}$ と極端に少ないため, セメン 
表 1 ライナーとロングストリングの比較

\begin{tabular}{|l|c|c|}
\hline & ライナー & ロングストリング \\
\hline シュー位置 & 自由度高 & 自由度なし \\
\hline 管内容量 & $600 \mathrm{bbl}$ & $1,000 \mathrm{bbl}$ \\
\hline セメントのコンタミ & 可能性低 & 可能性高 \\
\hline ECD & 低い & 高い \\
\hline 逸泥 & 可能性低 & 可能性高 \\
\hline セメンチング成功 & 可能性高 & 可能性低 \\
\hline & $\begin{array}{c}\text { アニュラスセメント } \\
\text { ライナーパッカー } \\
\text { バリア }\end{array}$ & $\begin{array}{c}\text { アニュラスセメントクャメント } \\
\text { タ゚ックオフシール } \\
\text { タイバックシール }\end{array}$ \\
\hline APB によるケーシング破損* & 可能性低 & 可能性低 \\
\hline タイバック時のトラブル & 可能性あり & 可能性なし \\
\hline 仕上げ費用 & 高い & 低い \\
\hline
\end{tabular}

*16" ケーシングにラプチャーディスクを使用していたため, どちらのケースも APB によるケーシング破損の可能性は低い

トと泥水がコンタミする可能性が高くなった。ライナーの 場合，管内容量が $600 \mathrm{bbl}$ とロングストリングに比べ少な いため, セメントと泥水がコンタミする可能性が低くなつ たと考えられる。

ライナーの場合ロングストリングに比べ，等価循環泥水 比重が低く，逸泥の可能性を最小限にとどめ，セメンチン グが成功する可能性を高められた。また，ライナーの場合 アニュラスにはセメント, ライナーパッカー, タイバック セメントおよびタイバックシールの 4 つのバリアを設ける ことができるため，ロングストリングに比べ坑井の健全性 も高められた。

\section{2 セメンチング}

圧縮強度試験が完了していないにもかかわらず，またセ メンチングモデルシミュレーションの結果高いガスフロー ポテンシャルが指摘されたがそのリスクを分析，評価する ことなく窒素セメントによるセメンチングを実施した。

アニュラス圧力上昇時に備え $16 "$ ケーシングにラプ チャーディスクを使用していたにもかかわらず，アニュラ ス圧力上昇を防止する目的で 9-7/8”ケーシング管内まで セメントを上げない計画であったため，セメントスラリー 量が極端に少なく，またロングストリングの管内容量がセ メントスラリー量に比べ極端に多く, 泥水とセメントのコ ンタミが発生した。

逸泥を軽減するために低ポンプレートでセメンチングを 実施したことによるセメントと泥水の置換効率の悪化およ び捨て穴に重泥をスポットしなかったため，セメントと泥 水の置換が発生したと考えられる。セメンチング前にボト ムアップを実施しなかったため，ガスがセメントに溶け込 み，セメントの強度が十分保たれなかった可能性も考えら れる。

フロートカラーが破損もしくは異物の詰まりにより, バックバルブが効いていなかった可能性があり，セメンチ ング終了後のフローバックの確認時にペンシルストリーム が見られたにもかかわらず，リグのヒービングによるもの と判断した。

\section{6. 考えられる対策}

ロングストリングに比べ管内容量の少ないライナーを採 用することでセメントが泥水とコンタミする可能性を低く できると考える。また， ライナーの場合シューを元肌直上 にセットできるため, 捨て穴でのセメントと泥水の置換を 最小限にとどめることができる。ライナーパッカーを使用 すればアニュラスの第 2 バリアとなり, 坑井の圧力遮断の 信頼性を高めることができた。

16 " ケーシングに使用されたラプチャーディスクにより アニュラス圧力上昇対策を取っていたので，セメントを 9-7/8" ケーシング管内まで上げる十分な量のセメントスラ リーを送ることで泥水とのコンタミを軽減できたと考える。

仮廃坑する際に $7^{\prime \prime} \times 9-7 / 8^{\prime \prime}$ ケーシング管内にセメント プラグもしくはメカニカルプラグをセットし，第 2 , 第 3 のバリアを設け坑井の健全性を高める必要があった。

また，ケーシングをセットせず，裸坑部にセメントプラ グをセットして仮廃坑するというオプションを選択する価 值はあると考える。このオプションを選択した場合，ケー シングデザインやセメンチングデザインを含む坑井デザイ ンを見直す機会が得られていたと考える。

\section{SI 単位換算係数}

\begin{tabular}{ll}
$\mathrm{psi} \times 6.894757$ & $\mathrm{E}+03=\mathrm{Pa}$ \\
$\mathrm{bbl} \times 1.589874$ & $\mathrm{E}-01=\mathrm{m}^{3}$ \\
$\operatorname{inch}\left(^{\prime \prime}\right) \times 2.54 *$ & $\mathrm{E}-02=\mathrm{m}$ \\
$\mathrm{ft} \times 3.048$ & $\mathrm{E}-01=\mathrm{m}$ \\
$\mathrm{ppg} \times 1.198$ & $\mathrm{E}+02=\mathrm{kg} / \mathrm{m}^{3}$ \\
\hline *は正確な值 &
\end{tabular}

参 考 文 献

The Bureau of Ocean Energy Management, Regulation and Enforcement, 2011 : Report regarding the Causes of the April 20, 2010 Macondo Well Blowout. 